\title{
El fallo dictado por la Corte Interamericana de Derechos Humanos en el caso "La Última Tentación de Cristo" puede y debe ser cumplido por el Estado de Chile de manera inmediata, sin necesidad de esperar una modificación legal por parte del Poder Legislativo ${ }^{\star}$
}

\author{
Matias Insunza Tagle \\ Egresado de Derecho \\ Universidad de Chile
}

El presente informe tiene por objeto demostrar que el fallo dictado por la Corte Interamericana de Derechos Humanos en el caso "La Última Tentación de Cristo" puede y debe ser cumplido por el Estado de Chile mediante la exhibición pública del filme, para lo cual basta que el Consejo de Calificación Cinematográfica aplique la teoría de la extinción del acto administrativo. Para una mayor claridad de la exposición, en los capítulos sucesivos se desarrollarán los antecedentes jurídicos que avalan esta postura.

\section{Antecedentes previos}

Como bien sabemos, la Corte Interamericana de Derechos Humanos, dentro de su quincuagésimo período ordinario de sesiones, falló la causa № 11.803 denominada "La Última Tentación de Cristo". En efecto, con fecha 05 de febrero de 2001 se dio a conocer la sentencia que condenó al Estado de Chile por haber censurado el filme antes mencionado.

II. Análisis de la parte resolutiva del fallo

La Corte Interamericana de Derechos Humanos, luego de un acabado análisis tanto fáctico como jurídico del caso, decidió condenar al Estado Chileno por la censura impuesta a la

* Este trabajo se basa en la Memoria denominada "El Estado Chileno ante la Corte Interamericana de Derechos Humanos, caso La Última Tentación de Cristo", elaborada por el autor y Alex Muñoz Wilson en marzo de 2001 para optar al grado de Licenciado en Ciencias Juridicas y Sociales en la Universidad de Chile. 
película de Martin Scorsese denominada "La Última Tentación de Cristo". Al respeto, el tribunal internacional, por unanimidad, resolvió:

1. declara que el Estado violó el derecho a la libertad de pensamiento y de expresión consagrado en el artículo 13 de la Convención Americana sobre Derechos Humanos, en perjuicio de los señores Juan Pablo Olmedo Bustos, Ciro Colombara López, Claudio Márquez Vidal, Alex Muñoz Wilson, Matías Insunza Tagle y Hernán Aguirre Fuentes.

2. declara que el Estado no violó el derecho a la libertad de conciencia y de religión consagrado en el artículo 12 de la Convención Americana sobre Derechos Humanos, en perjuicio de los señores Juan Pablo Olmedo Bustos, Ciro Colombara López, Claudio Márquez Vidal, Alex Muñoz Wilson, Matías Insunza Tagle y Hernán Aguirre Fuentes.

3. declara que el Estado incumplió los deberes generales de los artículos 1.1 y 2 de la Convención Americana sobre Derechos Humanos en conexión con la violación del derecho a la libertad de pensamiento y de expresión señalada en el punto resolutivo 1 de la presente Sentencia.

4. decide que el Estado debe modificar su ordenamiento jurídico interno, en un plazo razonable, con el fin de suprimir la censura previa para permitir la exhibición de la película "La Última Tentación de Cristo", y debe rendir a la Corte Interamericana de Derechos Humanos, dentro de un plazo de seis meses a partir de la notificación de la presente Sentencia, un informe sobre las medidas tomadas a ese respecto.

5. decide, por equidad, que el Estado debe pagar la suma de US\$4.290 (cuatro mil doscientos noventa dólares de los Estados Unidos de América), como reintegro de gastos generados por las gestiones realizadas por las víctimas y sus representantes en los procesos internos y en el proceso internacional ante el sistema interamericano de protección. Esta suma se pagará por conducto de la Comisión Interamericana de Derechos Humanos.

6. decide que supervisará el cumplimiento de esta Sentencia y sólo después dará por concluido el caso.

Esta parte resolutiva del fallo tiene una trascendental importancia, ya que condena al Estado de Chile a reparar las consecuencia dañosas ocasionadas por la censura de la película tantas veces mencionada. Lo anterior no debe extrañarnos, debido a que la Corte, en virtud de lo preceptuado por el artículo 63 del Pacto de San José de Costa Rica, debe, en la medida que ello proceda, reparar las consecuencias de la medida o situación que ha configurado la violación de los derechos garantizados por la señalada Convención. En el caso en cuestión ello es del todo plausible, ya que no estamos en presencia de una violación a un derecho imposible de restablecer, como lo sería la vida, sino frente a la vulneración de un derecho que, sin lugar a dudas, puede recuperarse. Ello porque el derecho a la libertad de expresión, vulnerado por el Estado de Chile al censurar la película, es susceptible de ser reconstruido con pleno vigor. En definitiva, no nos enfrentamos a una situación en la que el derecho conculcado sólo es susceptible de cumplirse por equivalencia, como lo sería, a modo ejemplar, una indemnización pecuniaria en el caso de una muerte por torturas, sino que estamos en presencia de un caso donde el cumplimiento en naturaleza es perfecto, debido a que el derecho a la liber- 
tad de expresión puede ser restablecido al mismo estado en que se encontraba hasta antes de su vulneración.

III. El Estado de Chile está obligado a cumplir el fallo mediante la modificación del ordenamiento jurídico para permitir la pública exhibición del filme

Si bien el fallo dictado por la Corte Interamericana de Derechos Humanos no ordena directamente la exhibición pública de la película "La Última Tentación de Cristo", ello lo hace de manera indirecta, puesto que exige al Estado de Chile la modificación de su ordenamiento jurídico interno para terminar con la censura previa impuesta al mencionado filme. En efecto, el punto $\mathrm{N}^{\circ} 4$ de la parte resolutiva decide que:

“...el Estado debe modificar su ordenamiento jurídico interno, en un plazo razonable, con el fin de suprimir la censura previa para permitir la exhibición de la película "La Última Tentación de Cristo", y debe rendir a la Corte Interamericana de Derechos Humanos, dentro de un plazo de seis meses a partir de la notificación de la presente Sentencia, un informe sobre las medidas tomadas a ese respecto".

De este modo, el Estado de Chile debe cumplir el fallo modificando el ordenamiento jurídico nacional para terminar con la censura previa y así poder exhibir libremente la película ${ }^{1}$. En consecuencia, nuestro país cumplirá el fallo una vez que modifique el ordenamiento jurídico que impide la exhibición del filme.

Tal como se demostrará al analizar el capítulo relativo a la extinción del acto administrativo, el Gobierno del Estado de Chile tiene en sus manos la posibilidad de cumplir este fallo de manera inmediata, sin que sea necesario esperar que el Poder Legislativo modifique la legislación que permite censurar previamente.

El ordenamiento jurídico ha sido definido como:

"el conjunto de normas jurídicas (derecho objetivo) que, formando un sistema, tiene vigencia en cierta época en un determinado grupo social, homogéneo y autónomo."2

Al respecto, don Máximo Pacheco Gómez, Juez de la Corte Interamericana de Derechos Humanos que concurrió con su voto favorable a la condena al Estado de Chile en el caso "La Última Tentación de Cristo", señala:

"La Teoría del ordenamiento jurídico positivo, expuesta originalmente por Adolfo Merkel (18361896), y desarrollada luego por Hans Kelsen (1881-1973) y Alfred Veldross, establece que el complejo de normas jurídicas que dan sentido al Derecho de un país no se encuentran aisladas,

1 Al respecto, cabe recordar que el artículo 68.1 de la Convención Americana de Derechos Humanos dispone: "Los Estados Partes en la Convención se comprometen a cumplir la decisión de la Corte en todo caso en que sean partes."

2 Alesandri, Somarriva y Vodanovic. Derecho Civil. Parte Preliminar y Parte General. Edit. Jurídica de Chile, $5^{2}$ Edición, 1990, p. 8. 
sino vinculadas entre sí por una fundamentación unitaria, en virtud de la cual constituyen una estructura, una unidad, un sistema denominado ordenamiento jurídico." 3

Luego el autor, siguiendo la Teoría Pura del Derecho de Kelsen plantea:

"Inmediatamente después de la Constitución vienen las normas generales emanadas del procedimiento legislativo, las cuales determinan no sólo los órganos y el procedimiento, sino también y sobre todo, el contenido de las normas individuales que han de ser dictadas para las autoridades judiciales y administrativas".

Sobre el particular, Kelsen señala:

"las sentencias de los tribunales son también verdaderos actos creadores de derecho, puesto que solamente merced a ellas se comprueba la existencia de un hecho ilícito y se aplica una sanción. Toda sentencia judicial es una norma jurídica individual que constituye una nueva etapa en el proceso de creación del derecho"4.

Con respecto a la autoridad administrativa, el autor alemán continúa diciendo:

"la administración tiene también por función individualizar y concretar las leyes. En gran parte de su actividad desempeña el mismo papel que la jurisdicción, esforzándose, como ésta, a obtener la conducta social deseada por el legislador al recurrir a actos de coacción en casos de conducta contraria".

A su vez, sobre los particulares, el profesor Pacheco, citando a Kelsen manifiesta:

"Los particulares, utilizando las facultades que les son delegadas por la ley, crean normas concretas para regular su conducta recíproca, éstos son los actos jurídicos de derecho privado" 5 .

Así, queda de manifiesto que no sólo forman parte integrante del ordenamiento jurídico las normas legales emanadas del Congreso Nacional, que tienen el carácter de generales, sino que también lo integran las normas particulares, dentro de las cuales se encuentran, entre otras, las sentencias judiciales y los actos jurídicos. De este modo, al ser el ordenamiento jurídico un sistema integrado por el conjunto de normas jurídicas vigentes en una época dentro de un determinado grupo social, homogéneo y autónomo, no sólo forman parte de éste las normas contempladas en la constitución, leyes, decretos y reglamentos, sino también las normas particulares, como lo son las sentencias judiciales y los actos jurídicos. Así las cosas, tanto un acto jurídico emanado de la autonomía de la voluntad de los particulares, como una sentencia judicial dictada por algún tribunal que resuelva un asunto específico, integran el ordenamiento jurídico. Del mismo modo, forman parte integrante de este todo denominado

\footnotetext{
Pacheco Gómez, Máximo. “Teoría del Derecho”. Editorial Jurídica de Chile, cuarta edición, 1990, p. 395.

Kelsen, Hans. "Teoría Pura del Derecho", Editorial Universitaria de Buenos Aires, novena edición, 1970, p. 152.

Pacheco Gómez, Máximo. Op. cit., p. 301.
} 
ordenamiento jurídico los actos jurídicos emanados de la autoridad administrativa denominados actos administrativos. En efecto, los actos administrativos han sido definidos como:

"la declaración de voluntad general o individual de un órgano administrativo emitida en función de una potestad o competencia administrativa, y por la cual se deciden o emiten juicios sobre derechos, deberes o intereses de las entidades administrativas, o de los particulares respecto de ésta." 6

Al ser un hecho inconcuso que los actos dictados por la administración chilena forman parte integrante del ordenamiento jurídico nacional, y considerando el carácter dinámico que posee este último concepto, queda de manifiesto que los mencionados actos pueden ser modificados por la propia autoridad que los dictó. En virtud de lo anterior, la alteración de un acto administrativo provocará, en el ámbito que corresponda, una modificación del ordenamiento jurídico nacional.

\section{Jerarquía del Pacto de San José de Costa Rica}

Si bien la jerarquía de los tratados internacionales de derechos humanos no ha sido un tema pacífico en doctrina, es un hecho inconcuso que, salvo contadas excepciones, tanto autores expertos en el tema de Derechos Humanos como constitucional, han llegado a la convicción que los tratados internacionales relativos a Derechos Humanos, que se encuentren vigentes en Chile, tienen rango constitucional ${ }^{7}$. Ello en atención a lo preceptuado por el inciso segundo del artículo $5^{\circ}$ de nuestra carta fundamental, el cual señala: "El ejercicio de la soberanía reconoce como limitación el respeto a los derechos esenciales que emanan de la naturaleza humana. Es deber de los órganos del Estado respetar y promover tales derechos, garantizados por esta Constitución, así como por los tratados internacionales ratificados por Chile y que se encuentren vigentes".

El artículo 13 del Pacto de San José de Costa Rica señala:

"1.Toda persona tiene derecho a la libertad de pensamiento y de expresión. Este derecho comprende la libertad de buscar, recibir y difundir informaciones e ideas de toda índole, sin consideración de fronteras, ya sea oralmente, por escrito o en forma impresa o artística, o por cualquier otro procedimiento de su elección.

2. El ejercicio del derecho previsto en el inciso precedente no puede estar sujeto a previa censura sino a responsabilidades ulteriores, las que deben estar expresamente fijadas por la ley y ser necesarias para asegurar: a. el respeto a los derechos o a la reputación de los demás, o b. la protección de la seguridad nacional, el orden público o la salud o la moral públicas.

3. No se puede restringir el derecho de expresión por vías o medios indirectos, tales como el abuso de controles oficiales o particulares de papel para periódicos, de frecuencias radioeléctricas, o de enseres $y$ aparatos usados en la difusión de información o por cualesquiera otros medios encaminados a impedir la comunicación y la circulación de ideas y opiniones.

Silva Cimma, Enrique. "Derecho Administrativo Chileno y Comparado". Edit. Jurídica de Chile, 1995, Tomo V, p. 26. Entre estos autores se encuentran el ex Ministro de Justicia don Frańcisco Cumplido, la Presidenta del Comité de DD.HH. de la ONU Cecilia Medina Q.; Humberto Nogueira A.; Mario Verdugo M.; José Zalaquett D.; etc. 
4. Los espectáculos públicos pueden ser sometidos por la ley a censura previa con el exclusivo objeto de regular el acceso a ellos para la protección moral de la infancia y la adolescencia, sin perjuicio de lo establecido en el inciso 2 .

5. Estará prohibida por la ley toda propaganda en favor de la guerra y toda apología del odio nacional, racial o religioso que constituyan incitaciones a la violencia o cualquier otra acción ilegal similar contra cualquier persona o grupo de personas, por ningún motivo, inclusive los de raza, color, religión, idioma u origen nacional." (lo destacado es nuestro).

De este modo, si el artículo 13 del Pacto de San José de Costa Rica prohíbe expresamente la censura previa, queda de manifiesto que existe una contradicción con el inciso final del artículo 12 de la constitución chilena, que señala: "La ley establecerá un sistema de censura para la exhibición y publicidad de la producción cinematográfica". Pues bien, frente a este conflicto normativo, se ha estimado que no sólo se debe privilegiar aquella dictada en forma posterior, sino, por sobre todo, aquella que de mejor manera protege, resguarda y garantiza los derechos humanos. Esta ha sido la interpretación que los tribunales de justicia le han dado, ya que en innumerables fallos se ha estimado que las normas internacionales que prohíben la prisión por deudas priman por sobre aquellas que vulneran dicho principio, tales como las leyes tributarias o de cheques. En el caso en comento la situación es clara, el Pacto de San José de Costa Rica es, además de posterior a la Constitución de 1980, una norma que protege de mejor manera el derecho a la libertad de expresión, ya que prohíbe la censura.

En consecuencia, y atendido que los derechos contemplados en el Pacto de San José de Costa Rica tienen rango constitucional, los actos administrativos dictados con anterioridad a su entrada en vigencia, si bien nacieron sanos y sin vicios, se tornaron ilegales por dicha causa sobreviniente, lo que -tal como detallaremos en los capítulos sucesivos- obliga a la administración a corregir, mediante la teoría de la invalidación por causa sobreviniente o decaimiento, el acto administrativo contrario a derecho.

Con todo, no podemos dejar de mencionar que, para un sector minoritario de la doctrina nacional, los tratados de derechos humanos no tienen rango constitucional, sino simplemente legal ${ }^{8}$. Pues bien, para aquellos que adscriben esta postura la conclusión debe ser la misma, ya que el acto administrativo dictado por el Consejo de Calificación Cinematográfica el año 1989, que censuró el filme "La Última Tentación de Cristo", se habría tornado ilegal y, por ende, la administración debe invalidarlo por causa sobreviniente o bien declarar su decaimiento. En efecto, si estimamos que el Pacto de San José de Costa Rica tiene sólo rango legal, quiere decir que en Chile, desde el año 1991, existe una ley que prohíbe la censura previa. Pues bien, y atendido que el D.L. N 679 que establece la posibilidad de prohibir la exhibición de un film es del año 1974, no cabe más que concluir que se aplica íntegramente el adagio jurídico "la norma posterior deroga a la anterior, cuando se refieren a la misma materia". Esto porque un D.L. tiene, no obstante haber sido dictado durante un régimen de facto, rango legal, que es igual al rango que, según estos autores, tendría el Pacto de San José de Costa Rica.

Entonces, sea que consideremos que el Pacto de San José de Costa Rica tiene rango constitucional, o simplemente legal, arribamos a la misma conclusión: el acto administrativo

8 Entre estos autores están: Pablo Rodríguez G.; Eduardo Sotto K. y Gustavo Fiamma. 
dictado por el Consejo de Calificación Cinematográfica el año 1988, y confirmado por el órgano de apelación en 1989, no obstante haber nacido sin vicios, se transformó en un acto administrativo contrario al ordenamiento jurídico chileno, por contravenir la constitución o ley, respectivamente.

En consecuencia, debido que el acto administrativo dictado el año 1989 contraviene abiertamente la legislación chilena, la administración, por intermedio del Consejo de Calificación Cinematográfica, debe invalidarlo por causa sobreviniente, o bien declarar su decaimiento.

\section{La extinción del acto administrativo}

En este capítulo abordaré la fórmula de cumplimiento que en mi parecer debe utilizarse para cumplir con el fallo dictado por la Corte Interamericana de Derechos Humanos que condenó al Estado de Chile en el caso "La Última Tentación de Cristo". Esta se fundamenta en la extinción del acto administrativo, específicamente en la teoría del decaimiento del acto administrativo o invalidación por causa sobreviniente.

\section{V.1. Generalidades}

El acto administrativo ha sido definido como:

"la declaración de voluntad general o individual de un órgano administrativo emitida en función de una potestad o competencia administrativa, y por la cual se deciden o emiten juicios sobre derechos, deberes o intereses de las entidades administrativas, o de los particulares respecto de ésta." .

El profesor Eduardo Soto Kloss lo define como:

"una ordenación racional dictada en forma unilateral por un sujeto dotado de potestad administrativa para satisfacer una necesidad pública concreta y con efectos jurídicos directos" 10 .

Otros han definido el acto administrativo, en su sentido estático, esto es, objetivo, como una declaración de voluntad orgánica administrativa formulada en el ejercicio de una potestad administrativa; y, en su aspecto dinámico, se traduce en una declaración de voluntad, de conocimiento, juicio o razonamiento formulada por un administrador, en el ejercicio de una potestad administrativa ${ }^{11}$.

\footnotetext{
Silva Cimma, Enrique. "Derecho Administrativo Chileno y Comparado". Edit. Jurídica de Chile, 1995, Tomo V, p. 26. Soto Kloss, Eduardo. Apuntes de clase del curso de Derecho Administrativo. Escuela de Derecho. Universidad de Chile, 1997. Pantoja Bauzá, Rolando. "Concepto de Acto Administrativo", Edit, Jurídica de Chile, 1960, citado por Hugo A. Olguín Juárez. "Extinción de los Actos Administrativos, Revocación, Invalidación y Decaimiento", Ed. Jurídica de Chile, 1961, p. 19.
} 
Con todo, la eficacia de los actos administrativos, o sea, su aptitud o capacidad de producir efectos, no sólo puede interrumpirse temporalmente, sea por razones de validez o de conveniencia u oportunidad, sino que puede cesar en forma definitiva. Esta cesación se produce cuando el acto se extingue ${ }^{12}$. Se entiende por extinción del acto administrativo su cesación y acabamiento; la eliminación del mundo jurídico en que tiene existencia. Este acabamiento del acto se produce tanto por su eliminación como por la cesación definitiva de sus efectos ${ }^{13}$. Es el cese total, completo y definitivo del acto mismo y por consiguiente también de sus efec$\operatorname{tos}^{14}$.

Si bien no es mi intención abocarme en este informe a un estudio pormenorizado del acto administrativo, es dable señalar que dentro de las causales de extinción de los actos administrativos se encuentran, entre otras, la nulidad, la revocación, la invalidación y el decaimiento. Estas causales de extinción pueden tener su origen en la propia administración, como es el caso de la revocación, decaimiento e invalidación, o bien en el órgano jurisdiccional, como la nulidad.Veamos algunas generalidades de cada una de ellas.

1) La Nulidad: Es una causal de extinción de los actos administrativos por el incumplimiento de los requisitos exigidos por la Constitución para la validez de los actos, provocada por la autoridad jurisdiccional mediante la dictación de una sentencia judicial. La nulidad del acto administrativo supone el ejercicio de una potestad jurisdiccional, diferenciándose por ello de aquellas causales que corresponde ejercer a los propios órganos de la administración, como la invalidación. El profesor Eduardo Soto Kloss define la nulidad de derecho público como aquella sanción que afecta a los actos que contravengan los requisitos de validez que estipulan los incisos $1^{\circ}$ y $2^{\circ}$ del artículo 7 de la Constitución, sanción que les afecta ipso iure, de pleno derecho y, consecuencialmente, de modo insanable e imprescriptible" 15 . Algunas de estas características, como su aplicación ipso iure, han sido controvertidas por otros profesores de Derecho Administrativo, entre ellos Jorge Reyes Riveros, Pedro Pierry Arrau y Enrique Silva Cimma ${ }^{16}$.

2) La Revocación: Se ha definido como la medida que adopta la propia Administración Activa tendiente a dejar sin efecto un acto administrativo por causa de mérito, oportunidad o conveniencia, vale decir, cuando la ponderación del bien común así lo hace aconsejable ${ }^{17}$. Se fundamenta en la mutación superviniente de alguno de los presupuestos del acto jurídico original; en la modificación de las exigencias de interés público que debe

12 Olguín Juárez, Hugo A. "Extinción de los Actos Administrativos, Revocación, Invalidación y Decaimiento", Ed. Jurídica de Chile, 1961 , p. 31.

13 Ibíd.

14 Silva Cimma, Enrique, "Derecho Administrativo Chileno y Comparado", Edit. Jurídica de Chile, 1995, Tomo V, p.152.

15 Soto Kloss, Eduardo. Apuntes de clases de Derecho Administrativo, Santiago, Escuela de Derecho, Universidad de Chile, Santiago, 1997.

16 Reyes R., Jorge. "La Nulidad de Derecho Público”, Ed. Jurídica Conosur, Stgo de Chile, 1998; Pedro Pierry A. "La Nulidad en el Derecho Administrativo", en Revista de Derecho, Universidad Católica de Valparaíso, XV (1993-1994), pp. 84 y 85; Enrique Silva C. "Derecho Administrativo Chileno y Comparado", Edit. Juridica de Chile, 1995, Tomo V, p. 145.

17 Silva Cimma, Enrique. "Derecho Administrativo Chileno y Comparado", Edit. Jurídica de Chile, 1995, Tomo V, p.154. 
satisfacer la administración ${ }^{18}$. En términos generales, es el retiro de los actos válidamente emitidos en razón de mérito ${ }^{19}$.

En general, se habla de revocación del acto administrativo para aludir a aquellas declaraciones de la Administración Activa y no de la Administración Jurisdiccional. Mucho se ha discutido en doctrina acerca de si la potestad revocatoria es o no de la esencia del acto administrativo, pero en general se ha concluido que ella no es consustancial a dicho acto, por lo que se prefiere plantear que ellos - generalmente- serán y podrán ser revocados ${ }^{20}$.

3) La Invalidación: Por invalidación, a la inversa de lo que ocurre con la revocación, se extinguen todos los actos irregulares, entendiéndose por tales a los viciados en su estructura al momento de emitírseles ${ }^{21}$. Es la declaración que formula la Administración Activa por cuyo intermedio deja sin efecto un acto administrativo por causas de ilegalidad. Su fundamento se encuentra en el deber que le asiste a la autoridad de ajustar sus actos a la observancia del principio de legalidad, postulado que en nuestra legislación es obligatorio para todos los órganos de la Administración del Estado por mandato de los artículos 6 y 7 de la Constitución Política, y 2 de la Ley Orgánica Constitucional de Bases Generales de la Administración del Estado $N^{\circ} 18.575$ de $1986^{22}$. Con respecto a quienes están revestidos de esta facultad invalidatoria, la doctrina está dividida. En efecto, el profesor Eduardo Soto Kloss limita considerablemente esta facultad de la administración, señalando que ella sólo puede ejercerla en el evento que el acto respectivo no haya generado derechos adquiridos para terceros de buena fe y, en caso contrario, sólo puede invalidar un acto administrativo una sentencia judicial ${ }^{23}$. Por el contrario, otros profesores como los señores Pedro Pierry Arrau y Jorge Reyes Riveros son de un parecer contrario, ya que plantean que la invalidación es una facultad que posee la autoridad administrativa ${ }^{24}$. Por ende, para estos últimos autores la administración tendría una facultad amplia para invalidar los actos contrarios a derecho.

4) El Decaimiento: Puede decirse que se llama decaimiento:

"a la pérdida de eficacia que experimenta un acto administrativo por circunstancias supervivientes que hacen desaparecer un presupuesto de hecho o de derecho, indispensable para su existencia" 25 .

El acto decae por un motivo superviviente, esto es, consiste en la extinción de un acto válidamente emitido, sin que medie una razón directa de interés público que provoque una

18 Diez, Manuel María. "El Acto Administrativo", Edit. Tipográfica, Editora Argentina S.A., Buenos Aires, 1961, p. 306, citado por Mónica Madariaga Gutiérrez, en su libro "Seguridad Juridica y Administración Pública en el Siglo XX”, p. 101.

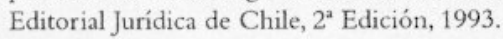

19 Olguín Juárez, Hugo A. Op. cit., p. 61.

20 Silva Cimma, Enrique. Op. cit., p. 154.

21 Olguín Juárez, Hugo A. Op. cit., p. 231.

22 Silva Cimma, Enrique, Op. cit., p. 159.

23 Soto Kloss, Eduardo. "La Invalidación de los Actos Administrativos en el Derecho Chileno", Rev. Derecho $\gamma$ Jurisprudencia, T.LXXXV, N³, 1988, Primera Parte.

24 Reyes R., Jorge, Op. cit., p. 43 y ss.; Pedro Pierry A., Op. cit., p. 84, 85.

25 Sayagués Laso, Enrique. "Tratado de Derecho Administrativo", Edit. Talleres Bianchi-Altuna, Montevideo, 1953, p. 519, citado por Hugo A. Olguín Juárez, Op. cit., p. 269. 
reacción de parte del órgano administrativo dirigida a extinguir sus efectos - como sucede en la revocación-, antes bien, la simple ocurrencia de un hecho sustrae al acto el contenido presupuestal de hecho o de derecho, y lo obliga a extinguirse, o sea, a decaer. El decaimiento, en consecuencia, se produce siempre que se altere un presupuesto básico que se tuvo en cuenta para la dictación del acto, entendiéndose por presupuesto la circunstancia material en que se basa la determinación administrativa -presupuesto de hecho-, o la exigencia jurídica que debe satisfacer el acto para adaptarse al contenido jurídico vigente - presupuesto de derecho-. El contenido jurídico del decaimiento no es otro, consiguientemente, que la imposibilidad de eficacia de un acto administrativo, o su eficacia violatoria del sistema normativo vigente, como consecuencia de una ilegitimidad sobreviniente ${ }^{26}$.

Según lo expuesto, podemos definir el decaimiento como:

"la extinción de un acto administrativo provocada por circunstancias sobrevinientes de hecho o de derecho que afectan su contenido jurídico tornándolo inútil o abiertamente ilegítimo"27.

No obstante las semejanzas entre el decaimiento y las mencionadas causales de extinción de los actos administrativos, existe una serie de diferencias entre ellas.

a) Diferencias entre decaimiento y revocación:

i) El decaimiento se produce por la ocurrencia de un hecho que tiene la virtud de hacer perder la eficacia de un acto administrativo, haciendo desaparecer un presupuesto de hecho o de derecho indispensable para su existencia. La revocación, por el contrario, se produce por una nueva manifestación de la voluntad administrativa, orientada en el sentido de extinguir la eficacia de un acto administrativo anterior, porque sus efectos son contrarios al interés público actual.

ii) El fundamento de la revocación es el demérito sobreviniente. El fundamento del decaimiento es la inutilidad del acto o la ilegitimidad posterior ${ }^{28}$.

b) Diferencias entre el decaimiento y la invalidación:

i) La invalidación es un retiro de un acto contrario a derecho, o sea, la extinción de un acto por los vicios originarios que lo aquejaban, la muerte de un acto inválido. Decaen, en cambio, los actos válidamente emitidos, por la ocurrencia de un hecho que los hace inútiles o ilegítimos a posteriori.

ii) La invalidación necesita ser declarada, en tanto que el decaimiento se produce por la desaparición del presupuesto fáctico o jurídico indispensable para la existencia del acto, necesitando la sola verificación del hecho, es decir, que se certifique la muerte del acto. Es por esto que resulta indiscutible la naturaleza declarativa del acto que verifica el decaimiento, en cambio, algunos autores discuten dicha naturaleza en el acto de invalidación ${ }^{29}$.

\footnotetext{
26. Olguín Juárez, Hugo A. Op. cit., p. 269.

Piccinini García, Doris. "Teoria del Decaimiento de los Actos Administrativos", Ed. Jurídica de Chile, 1968.

Olguín Juárez, Hugo. Op. cit., p. 276.

Olguin Juárez, Hugo. Op. cit., p. 277.
} 
En palabras de Mónica Madariaga Gutiérrez:

"el decaimiento es una figura jurídica que extingue un acto administrativo por la ocurrencia de hechos que son ajenos a la voluntad de la administración" 30 .

De este modo, las causales del decaimiento pueden ser: 1) Una imposibilidad de producción de efectos, y 2) Una ilegitimidad sobreviniente.

1) Imposibilidad de producción de efectos:

En este caso, la sustancia o contenido del acto decae por la ocurrencia de un hecho que hace imposible su eficacia. El acto decae por inútil.

2) Ilegitimidad sobreviviente:

Aquí el acto decae porque sus efectos son violatorios del ordenamiento jurídico, esto es, el acto deviene ilegítimo. Así, en el decaimiento el acto muere por una enfermedad adquirida, no por un vicio originario como sucede en la invalidación.

Puede decirse, en síntesis, que las causas del decaimiento son, entonces:

a) La desaparición de un presupuesto de hecho indispensable para la validez del acto, v.gr: La destrucción de un terreno de playa objeto de una concesión, la muerte de un funcionario público, etc.

b) La derogación del precepto legal en que se funda el acto, cuando dicha regla era indispensable para su vigencia, v.gr: derogación de una ley que es la base indispensable para la vigencia de un reglamento general, y

c) La modificación del régimen legal, en términos tales, que constituya un impedimento para el mantenimiento del acto ${ }^{31}$.

En estos últimos casos, el acto administrativo sigue produciendo sus efectos, es decir, sigue siendo eficaz, pero esta eficacia debe cesar porque es contraria a derecho. Así, los efectos del acto devienen ilegítimos, no hay convergencia entre el sistema normativo y el acto administrativo. En este caso, el fundamento del decaimiento radica en que no es posible la mantención de un acto administrativo contrario a las normas.

En todo caso, continúa la Sra. Madariaga, en las situaciones consignadas en la letra c) será siempre necesario establecer si al amparo del acto administrativo se consolidaron situaciones constitutivas de derechos adquiridos, en cuyo caso la modificación del régimen jurídico no los afectará sino con sujeción a las normas constitucionales que prevén los únicos casos o situaciones en que pueden verse afectados los derechos patrimoniales (v.gr. expropiación) ${ }^{32}$.

30 Madariaga Gutiérrez, Mónica. "Seguridad Jurídica y Administración Pública en el Siglo XX",p. 106, Editorial Jurídica de Chile, 1993.

31 Madariaga Gutiérrez, Mónica. “Seguridad Jurídica y Administración Pública en el Siglo XX”, p. 106, Editorial Jurídica de Chile, 1993.

32 Ibid. 
De este modo, y siguiendo a Piccinini, podemos decir:

"Para que se produzca el decaimiento es necesario que las circunstancias supervivientes tengan una fuerza tal que tornen al acto inútil o abiertamente ilegítimo. En efecto, si ocurre una circunstancia de hecho que afecta el contenido del acto de manera que imposibilita materialmente y en forma definitiva la producción de sus efecto, el acto queda desprovisto de su contenido jurídico, pasa a ser un simple continente, un acto de papel y, por lo tanto, inútil. Así, por ejemplo, si en el acto de concesión se afecta su contenido por un hecho superviviente-destrucción de la playa-, o si en un acto de nombramiento para determinada función una norma objetiva suprime el cargo, tanto la concesión como el nombramiento carecen de objeto, y son sólo actos administrativos por su estructura formal. Nadie podría alegar derechos sobre un acto sin contenido o cuyo contenido ha decaído. Por otra parte, si una circunstancia de derecho es alterada en forma tal que se produzca la desvinculación del acto con la norma que lo sustentaba, se produce una divergencia actual entre norma y acto que no permite a éste producir válidamente sus efectos, originándose por ello una ilegitimidad sobreviniente que provoca su extinción." ${ }^{33}$

Por los argumentos que a continuación se señalan, es esta segunda situación la que se produce en el caso de "La Última Tentación de Cristo", ya que:

1) Tal como consta en el fallo de la Excma. Corte Suprema, dictado con fecha 17 de junio de 1997, se dejó sin efecto el acto administrativo dictado por el Consejo de Calificación Cinematográfica que el 11 de noviembre de 1996 autorizó la exhibición del filme "La Última Tentación de Cristo". En efecto, nuestro máximo tribunal confirmó el fallo de la Iltma. Corte de Apelaciones que, en la parte resolutiva pertinente, señala:

“...se acoge el recurso de protección deducido a lo principal de fojas 13 , y se declara que se deja sin efecto la resolución administrativa del Consejo de Calificación Cinematográfica adoptada en sesión $\mathrm{N}^{\circ} 244$, del 11 de noviembre de 1996, quedando, en consecuencia, firme aquella de 29 de noviembre de 1988, confirmada mediante el fallo del tribunal de apelación cuya copia se lee a fojas 151, de fecha 14 de marzo de 1989".

2) Al quedar sin efecto el acto administrativo dictado por el Consejo de Calificación Cinematográfica que autorizó la exhibición del filme, recupera plenamente su vigencia el acto administrativo dictado por el mismo ente el 29 de noviembre de 1988, confirmado el 14 de marzo de 1989, que prohibió la exhibición de "La Última Tentación de Cristo". Lo anterior es del todo obvio, ya que la Excma. Corte Suprema estimó que el acto administrativo dictado en noviembre de 1996 era ilegal y arbitrario, por lo que correspondía dejarlo sin efecto, con lo cual restableció la situación al mismo estado en que se encontraba hasta antes de su dictación, es decir, recuperó su validez y eficacia el acto administrativo de dicho Consejo que prohibió el filme en cuestión.

3) En consecuencia, tenemos que concluir que el acto administrativo que aún rige sobre la materia es aquel dictado el año 1989, es decir, aquel que rechazó la autorización para exhibir la película.

33 Piccinini, Doris. Op. cit., p. 62-63. 
4) Como bien sabemos, Chile el año 1989 aún se encontraba bajo el gobierno militar presidido por Augusto Pinochet Ugarte, que se prolongó por más de 16 años, hasta el 11 de marzo de 1990, fecha en la cual nuestro país recuperó su democracia. De este modo, el acto administrativo que hoy se encuentra vigente, y que impide exhibir el filme en comento, fue dictado durante el régimen militar, período en el cual en Chile se violaron sistemáticamente los Derechos Humanos, entre los cuales se encuentra la libertad de expresión.

5) La Convención Interamericana de Derechos Humanos o Pacto de San José de Costa Rica fue ratificada por Chile el año 1990, es decir, durante el primer año del gobierno del ex Presidente Patricio Aylwin Azócar.

6) Al haberse ratificado la Convención Americana de Derechos Humanos, ella se incorporó a nuestro ordenamiento jurídico, pasando a ser norma obligatoria para nuestro país.

7) Producto de lo anterior, debemos concluir que el acto administrativo del año 1989 fue válidamente dictado por el Consejo de Calificación Cinematográfica, ya que se adecuó a toda la normativa vigente a esa época. Pero una vez incorporada a nuestro ordenamiento jurídico la Convención Americana de Derechos Humanos, los efectos de dicho acto decayeron, ya que en virtud del artículo 13 de dicho Pacto se prohíbe la censura previa, la cual había sido impuesta por el mencionado Consejo el último año del gobierno.

8) La anterior conclusión es del todo razonable, ya que con posterioridad a la dictación del acto administrativo del año 1989 varió la legislación chilena sobre la materia, pasando a transformarse un acto enteramente lícito en ilícito por una situación sobreviniente, como lo fue la ratificación del Pacto de San José de Costa Rica. De este modo, estamos en presencia de una causal de invalidación por causa sobreviniente, la que los autores denominan decaimiento. En efecto, el acto del año 1989 no adolece de vicios coetáneos a su nacimiento, sino que él se tornó ilegal por un cambio de la legislación, que mutó de aquella que permitía la censura previa a una que la prohíbe expresamente.

9) Producto de lo anterior, el fallo condenatorio que dictó la Corte Interamericana de Derechos Humanos en contra del Estado de Chile no sólo obliga a este último a cumplirlo, sino que demuestra que en nuestro país rige desde el año 1991 el Pacto de San José de Costa Rica, el cual debe ser acatado.

10) Considerando tanto el fallo condenatorio como la incorporación indiscutida a nuestro ordenamiento jurídico del Pacto de San José de Costa Rica, queda de manifiesto que en Chile variaron las circunstancias jurídicas que existían el año 1989, época de dictación del acto administrativo que aún mantiene su vigencia. Es por esto que la ilegitimidad sobreviniente, que vicia dicho acto administrativo que nació sano, debe ser remediada por la administración.

11) Lo anterior es del todo lógico, ya que sobre la administración del Estado pesa la obligación de adecuar sus actos a la Constitución y a las normas dictadas de conformidad a ella, lo cual le impide tolerar la existencia de actos administrativos fundados en preceptos contrarios a la normativa vigente.

12) Vinculando el decaimiento con el principio de'legalidad consagrado en nuestra constitución en las artículos 6 y 7 llegamos a la misma conclusión precedente. En efecto, frente al 
hipotético caso de pérdida de un requisito legal, como sería, por ejemplo, la pérdida de la nacionalidad chilena (exigida por la ley para desempeñar cierto cargo), puede que el acto de nombramiento de la persona que en forma sobreviniente perdió dicha nacionalidad, produzca efectos aparentes, viciados de ilegalidad; sin embargo, no puede acusarse al acto de nombramiento (dictado cuando el sujeto era chileno) de estar viciado, ya que fue emitido legítimamente, ni puede tampoco pensarse en la existencia de un vicio a posteriori, puesto que vicio, en sentido estricto, significa una mala conformación estructural, y el acto conserva su estructura. Es por esto que:

"Si se mira el problema no ya del acto administrativo mismo cuyos efectos han devenido ilegales, sino de la autoridad administrativa que tiene a su cargo velar por la legalidad y que ha dejado hacer, que no ha certificado ni la falta presupuestal ni la extinción del acto de nombramiento como acto válido y que, en fin, permite tal estado de cosas, es evidente que existe una no actuación, un no hacer, un no certificar, precisamente cuando circunstancias presupuestales - cambio de requisitos o alteración de ellos por la persona nombrada- le obliga a actuar, a hacer, a certificar la cesación de efectos del acto administrativo. En este caso, claro está, existe un acto viciado, pero no es el acto de nombramiento que está produciendo efectos írritos al ordenamiento jurídico, sino el acto negativo estático de la autoridad administrativa que, al no certificar la muerte legal del acto, permitió la continuación de un estado de cosas desvinculado de la norma legal." ${ }^{34}$

13) Una vez constatada la circunstancia del cambio de normativa que tornó ilegítimo el acto administrativo que nació sin vicios, cabe preguntarse cuál debe ser la actitud del administrador. Algunos autores han planteado que el decaimiento se produce sin necesidad de una declaración posterior, esto es, ipso iure, operando sin necesidad de una declaración posterior $^{35}$. Otros, por el contrario, opinan que es necesario un acto de clausura, una manifestación de voluntad que revele el enervamiento del acto, o sea, el decaimiento se produce por un hecho, pero, para que ese hecho sea relevante, es menester una declaración posterior en el sentido de que el acto ha dejado de existir ${ }^{36}$. Parte de la doctrina es partidaria de una posición intermedia, señalando que en algunos casos el decaimiento operaría de pleno derecho y en otros se requiere de una manifestación de voluntad de la administración, en el sentido de declarar que el acto se ha extinguido ${ }^{37}$. En Chile la doctrina sigue una posición intermedia. En efecto, en el Informe del Seminario de Derecho Público de las Jornadas Chileno-Uruguayas de Derecho Comparado de 1959, el profesor y ex Presidente de la República don Patricio Aylwin Azócar, opina que sobre la materia no puede darse una regla uniforme, siendo preciso hacer una distinción relacionada con las causales del decaimiento. El decaimiento se produce, como sabemos, por una imposibilidad en la producción de los efectos del acto -decaimiento por inutilidad-o por una ilegitimidad sobrevenida -decaimiento por la carencia de un presupuesto de derecho-. Cuando el decaimiento se produce por una imposibilidad en la producción de

34 Piccinini, Doris. Op. cit., p. 84.

35 Sayagués Laso, Enrique. Op. cit., citado por H. Olguín, Op. cit., p. 273

36 Méndez. "Notas para un Estudio sobre los Caracteres de la Revocación", Imprenta El Siglo Ilustrado, Montevideo, 1949, citado por H. Olguín, Op. cit., p. 273.

Olguín Juárez, H. Op. cit., p. 273. 
efectos, es lógico que no sea necesario un acto que declare la muerte del acto inútil v.gr. término del período por el cual fue contratado ${ }^{38}$. Por el contrario, cuando el decaimiento se produce por una ilegitimidad sobreviniente, se hace necesaria la emisión de un nuevo acto de naturaleza declarativa que constate la muerte del anterior, haciendo notar su actual ilegitimidad ${ }^{39}$. De este modo, dicha declaración de voluntad constata, señala y demuestra que el acto se ha extinguido y, por ende, es necesario que exista, ya que declara la ilegitimidad sobreviniente, señalando que el acto carece de vida jurídica.

En este caso, nos encontramos frente a un caso de ilegitimidad sobreviniente, ya que el acto administrativo dictado el año 1989 se tornó ilícito luego que Chile ratificara la Convención Americana de Derechos Humanos que prohíbe la censura previa, lo cual se ve reafirmado con la sentencia condenatoria que dictó la Corte Interamericana de Derechos Humanos en contra de Chile. Producto de lo anterior, el decaimiento de los efectos del acto administrativo hoy vigente, esto es, aquel dictado el año 1989 que censuró el filme, no se produjeron de pleno derecho al ratificarse el Pacto de San José de Costa Rica ni tampoco con la sola dictación del fallo condenatorio, sino que se requiere una manifestación de voluntad que declare y constate la extinción del acto administrativo del año 1989, lo cual debe efectuarse mediante otro acto administrativo de carácter declarativo. Este nuevo acto de la administración debe ser dictado por el mismo Consejo de Calificación Cinematográfica que censuró el filme el año 1989, manifestando que la normativa hoy vigente, específicamente el artículo 13 del Pacto de San José de Costa Rica, prohíbe la censura previa, lo que se ve claramente confirmado por el fallo que condenó al Estado de Chile por haber violado dicha convención, sentencia que acredita sobradamente el cambio de las circunstancias jurídicas.

\section{V.2. El fallo de la Corte Interamericana de Derechos Humanos no vulnera la sentencia dictada por la Excma. Corte Suprema}

Ahora bien, la sentencia condenatoria que dictó la Convención Interamericana de Derechos Humanos en contra de Chile ¿¿deja sin efecto la sentencia de la Excma. Corte Suprema o está dirigida al acto administrativo que el año 1989 censuró el filme y que nuestro máximo tribunal confirmó su vigencia?

En este caso el acto que se verá afectado será el administrativo y no el jurisdiccional, ya que es él el que estableció la censura. Lo anterior se debe a que la Excma. Corte Suprema sólo ratificó la vigencia del acto administrativo del año 1989 mediante la anulación del acto administrativo del año 1996 que pretendió revocar la primitiva decisión del Consejo de Calificación Cinematográfica. En consecuencia, queda de manifiesto que la Excma. Corte Suprema no fue más que una de las vallas que hubo que sortear para cumplir con el requisito del

\footnotetext{
38 Al respecto, el Art. 147 del Estatuto Administrativo, Ley $N^{\circ} 18.834$, señala: "El término del período legal por el cual es nombrado el funcionario, o el cumplimiento del plazo por el cual es contratado, produce la inmediata cesación de sus funciones".

39 Aylwin Azócar, Patricio, "Informe Chileno sobre la Revocación y'Suspensión de los actos administrativos". Jornadas Uniguaya-Chilenas de Derecho Comparado, 1958, citado por H. Olguín Juárez, Op. cit., p. 274.
} 
agotamiento de los recursos internos que exige el artículo 46 del Pacto de San José de Costa Rica para poder acudir al órgano internacional.

La conclusión anterior debe entenderse sólo para el caso de "La Última Tentación de Cristo", y en ningún caso implica dejar proscrita la posibilidad de recurrir a la instancia internacional por una decisión del órgano jurisdiccional que, en definitiva, pueda ser alterada al momento que Chile cumpla con el fallo condenatorio que dictó dicha Corte Internacional, respectivamente. Lo anterior se debe - grosso modo- al hecho que la Corte Interamericana de Derechos Humanos, al condenar al Estado de Chile, lo declaró responsable internacionalmente por haber vulnerado la Convención Americana. Por ende, una sentencia que dicte algún tribunal nacional que vulnere las normas del Pacto de San José perfectamente puede verse afectada por una decisión de la Corte Interamericana, ya que no hay cosa juzgada, debido a que el elemento cosa pedida jamás será el mismo. Concluir lo contrario implicaría decir que nunca una decisión jurisdiccional, emanada de un órgano del Estado de Chile como el Poder Judicial -que por ende lo obliga-, podría ser impugnada ante la Corte Interamericana, lo cual es a todas luces absurdo.

De este modo, en el caso particular de "La Última Tentación de Cristo" no existe pugna alguna entre el fallo de la Excma. Corte Suprema chilena que confirmó la vigencia del acto administrativo del año 1989 y la sentencia de la Corte Interamericana, ya que esta última decisión jurisdiccional afecta directamente al acto administrativo que el año antes mencionado censuró la película.

Lo anterior se ve confirmado, además, por toda la teoría de la cosa juzgada formal del fallo del recurso de protección que, tal como dispone el artículo 20 de la Constitución, deja subsistente la posibilidad de ejercer los demás derechos que correspondan. En efecto, dicha norma señala, en la parte pertinente de su inciso $1^{\circ}$ :

“...podrá ocurrir por sí o por cualquiera a su nombre, a la Corte de Apelaciones respectiva, la que adoptará de inmediato las providencias que juzgue necesarias para restablecer el imperio del derecho y asegurar la debida protección del afectado, sin perjuicio de los demás derechos que pueda hacer valer ante la autoridad o los tribunales correspondientes." 40

Si el fallo del recurso de protección deja a salvo la posibilidad de hacer valer los demás derechos ante la autoridad o los tribunales correspondientes, entre los cuales indudablemente se encuentra la Corte Interamericana de Derechos Humanos, la condena dictada por este Tribunal en contra de Chile perfectamente puede afectar al acto administrativo que hoy se encuentra vigente, esto es, aquel dictado por el Consejo de Calificación Cinematográfica el año 1989. Lo anterior se debe a lo siguiente:

1) Como lo señalamos precedentemente, la Excma. Corte Suprema dejó sin efecto el acto administrativo dictado por el Consejo de Calificación Cinematográfica el año 1996, recuperando plena validez aquel dictado por este mismo Consejo el año 1989. Por ende, el acto administrativo hoy vigente es este último, que censuró el filme e impide actualmente su exhibición.

Constitución Política de la República de Chile, art. 20. 
2) Al existir cosa juzgada formal en el recurso de protección del caso de "La Última Tentación de Cristo" las víctimas pudieron, en virtud del artículo 20 de la Constitución, concurrir válidamente a la Corte Interamericana para solicitar que ésta declarare -tal como lo hizo- la responsabilidad internacional del Estado de Chile por haber violado el Pacto de San José de Costa Rica.

3) Como corolario de la declaración de responsabilidad internacional que estableció en contra de Chile la Corte Interamericana, dicho tribunal condenó a nuestro país, entre otras cosas, a "...modificar su ordenamiento jurídico interno, en un plazo razonable, con el fin de suprimir la censura previa para permitir la exhibición de la película..." ${ }^{41}$, es decir, a exhibir el filme censurado por el acto administrativo vigente desde el año 1989.

4) Así las cosas, y atendido que Chile se encuentre obligado a modificar su ordenamiento jurídico para poder exhibir el filme en cuestión en virtud de la sentencia dictada por la Corte Interamericana, no nos enfrentamos a dos fallos contrapuestos, sino que ellos son del todo compatibles entre sí. En efecto, el fallo del recurso de protección lo único que hizo fue dejar sin efecto el acto administrativo que el año 1996 recalificó el filme, recuperando su vigencia el acto dictado por el Consejo de Calificación Cinematográfica el año 1989 que lo censuró. Por su parte, la condena que impuso el tribunal internacional tiene su fundamento en la responsabilidad internacional de Chile.

5) Con todo, este fallo condenatorio que se dictó en contra de Chile ¿¿deja sin efecto el acto administrativo censurador del filme? Creo que si bien no lo puede hacer en forma directa, esto es, de pleno derecho, sí podría efectuarlo de manera indirecta; por medio de la teoría del decaimiento del acto administrativo.

Analicemos este método de cumplimiento del fallo condenatorio que afecta a Chile. Como Chile se encuentra obligado a cumplir el fallo dictado por la Corte Interamericana de Derechos Humanos, es perfectamente posible que para ello realice lo siguiente:

a) La Cancillería recibe una copia autorizada del fallo que condena a Chile.

b) Teniendo como antecedentes tanto el fallo de la Corte Interamericana como la incorporación a nuestro ordenamiento jurídico del Pacto de San José de Costa Rica, el Consejo de Calificación Cinematográfica debe, en virtud de la teoría del decaimiento del acto administrativo, dictar un nuevo acto administrativo que constate y declare que el acto administrativo censurador del año 1989 se ha tornado ilegítimo. En efecto, debe señalar y constatar que, en virtud de dichos antecedentes posteriores al año 1989 , fecha en que se dictó el acto censurador, el acto mutó de legal a ilegal, por lo que procede declarar su extinción mediante un nuevo acto administrativo que se acomode a la normativa vigente.

¿Podría impugnarse lo anterior mediante el argumento que el acto administrativo del año 1989 es inatacable e inmodificable?

41 Párrafo cuarto de la parte resolutiva del fallo dictado por la CIDH en la causa "La Última Tentación de Cristo". 
Como lo señalan los propios fallos de la Iltma. Corte de Apelaciones de Santiago y de la Excma. Corte Suprema, el acto administrativo dictado el año 1988, que censuró el filme, fue confirmado por el tribunal de apelación creado por el Decreto Ley $\mathrm{N}^{\circ} 679$, de $1^{\circ}$ de octubre de 1974, y Reglamento aprobado por el Decreto de Educación $N^{\circ} 376$, de $1^{\circ}$ de julio de 1975. En consecuencia, se produce una suerte de cosa juzgada emanada de la administración, ya que dicho tribunal ejerce facultades jurisdiccionales. Producto de lo anterior, señala el considerando $9^{\circ}$ del fallo de la Iltma. Corte de Apelaciones de Santiago:

“...no podía revisarse y, menos, revocarse la resolución de 29 de noviembre de 1988 confirmada por un tribunal de apelación jurisdiccional establecido por ley y para el efecto señalado. Al haberse revisado y revocado la referida resolución de 1988 (mediante el acto administrativo del año 1996 emanado del propio Consejo de Calificación Cinematográfica), confirmada por el fallo del tribunal de apelación mencionado, se incurrió en un acto ilegal."

\section{En la misma línea argumental, el considerando $10^{\circ}$ de dicho fallo señala:}

"Que, aunque no hubiere mediado una decisión jurisdiccional que hubiere producido el efecto de cosa juzgada, como se ha señalado, tampoco se justifica, en el caso que se estudia, la conveniencia ni la oportunidad de la resolución revocatoria de que se trata, en virtud de los principios de certeza jurídica, de inmutabilidad y de intangibilidad que deben caracterizar los actos administrativos; primero, porque la ley, (Decreto Ley $\mathrm{N}^{\circ} 679$, de 1974, y su Reglamento) no contempla causa alguna de revocabilidad de las resoluciones emanadas del Consejo de Calificación Cinematográfica, luego, porque no se aprecia la razón de la revocación de una resolución sin que hayan variado las circunstancias: el público es el mismo y la película la misma, pues no se sabe que se le hayan introducido modificaciones que determinen un cambio de opinión y, por último, no se divisa cuál es el fundamento de un mayor bien o interés público que podría justificar la revocación de la comentada decisión administrativa, de noviembre de 1988. Menos aún se entiende dicha revocación al haber sido confirmada por el tribunal de apelación señalado. En consecuencia, el acto administrativo que se impugna carece de razonabilidad, de motivo suficiente racional y de fundamento valedero, por lo cual, además de ilegal, resulta arbitrario."

\section{Por su parte, la Excma. Corte Suprema, manifiesta en su considerando $7^{\circ}$ :}

“Que la resolución 214, del 11 de noviembre de 1996, del Consejo de Calificación Cinematográfica, que ante la solicitud de la empresa interesada levanta el rechazo que había quedado firme en 1988, resulta así manifiestamente ilegal porque se vuelve contra lo que el órgano superior había definitivamente decidido; y lo es, además, porque se ha dictado en ejercicio de una potestad de revisión de que carece absolutamente la entidad mencionada, ya que no hay precepto legal alguno que la haya investido de tal poder revocatorio, estando -como se ha visto que lo está- especialmente regulado el procedimiento de revisión en caso de rechazo".

En consecuencia, los tribunales de justicia chilenos consideraron que el acto administrativo del año 1988, confirmado por el tribunal de apelación en 1989, se encontraba a firme y no podía ser revocado por el Consejo de Calificación Cinematográfica como éste pretendió en 1996 mediante el nuevo acto administrativo dejado sin efecto por el órgano jurisdiccional. De este modo, observamos dos conceptos que no podémos dejar de analizar. Por un lado está la cosa juzgada administrativa, y por el otro la revocación del acto administrativo. 
Ambos conceptos dan para un análisis mucho más extenso, por lo que sólo haremos una referencia genérica en lo que respecta al caso que nos ocupa.

\section{a. Cosa Juzgada Administrativa:}

Como señalan los considerando $9^{\circ}$ del fallo del recurso de protección dictado por la Iltma. Corte de Apelaciones de Santiago y $7^{\circ}$ del de la Excma. Corte Suprema, ambos trascritos precedentemente, el acto administrativo dictado el año 1988, confirmado el año 1989, estaría firme, ya que no podría revisarse ni menos revocarse; es decir, existiría una cosa juzgada que tornó invariable, inmodificable, intangible e inimpugnable el acto censurador del Consejo de Calificación Cinematográfica de 1989.

La teoría de la cosa juzgada administrativa ha sido ampliamente debatida por la doctrina. $\mathrm{Al}$ respecto, el profesor Silva Cimma señala:

"La cosa juzgada administrativa correspondería a la propiedad o atributos que presentarían los actos del Estado Administrador en orden a no ser modificables en ningún caso por actos de la misma especie o, de serlo, únicamente bajo determinadas condiciones" ${ }^{2}$.

Luego, el autor continúa señalando:

"Desde mi particular punto de vista, he sostenido desde antaño que la institución de la cosa juzgada propiamente tal no es trasladable al campo de los actos de la Administración Activa, y para ello he tenido en cuenta, por una parte, que en el ámbito del Derecho Administrativo no es dable admitir la existencia de derechos adquiridos en los términos que lo formula el Derecho Común, y por la otra, el carácter ejecutivo o ejecutorio de los actos administrativos, que posibilita que se cumplan tan pronto quedan afinados y por intermedio de la propia Administración, como igualmente el carácter revocable, sea por causa de mérito -revocación propiamente tal-o por causa de ilegalidad -invalidación- que ellos presentan" ${ }^{43}$.

Mucho se ha escrito sobre la estrecha vinculación entre la jurisdicción y la cosa juzgada. Así la Excma. Corte Suprema, en sentencia de 6 de marzo de 1989, declaró que:

"la jurisdicción es el poder que tienen los tribunales de justicia para resolver, por medio del proceso y con efectos de cosa juzgada, los conflictos de relevancia jurídica en cuya solución les corresponde intervenir..." 44

El máximo tribunal, en sentencia del 27 de julio de 1960, manifestó que:

“esa cosa juzgada es un atributo propio y exclusivo de la jurisdicción"45.

42 Diez, Manuel María. "El Acto Administrativo”, Bibliografia Omega, B. Aires, 1947, p. 264, citado por Enrique Silva Cimma, Op. cit, p. 265.

43 Silva Cimma, Enrique, Op. cit., p. 267.

44 Gaceta Juridica, año $1989, \mathrm{~N}^{\circ} 105, \mathrm{pp} .28$ y ss.

45 Revista de Derecho $\gamma$ Jurisprudencia, Tomo LXV, segunda parte, secc. Primera, p. 2. 
Autores destacados del Derecho Constitucional, como Maurice Duverger, y del Derecho Administrativo, como Gastón Jesé, tienen igual visión. Por su parte, Enrique Sayagués Laso aclara que aunque el acto administrativo sea definitivo por el agotamiento de los recursos administrativos procedentes:

"tiene cierta estabilidad que no puede confundirse con la cosa juzgada propia de las sentencias"

De este modo, la autoridad de cosa juzgada es una manifestación de la jurisdicción, la cual se ejerce por los órganos jurisdiccionales establecidos en nuestra legislación. Así, donde hay cosa juzgada hay jurisdicción ejercida por algún órgano de carácter jurisdiccional. En consecuencia, si se postula que el acto administrativo del año 1989 generó cosa juzgada, se debe aceptar que el tribunal administrativo de apelación que confirmó el año 1989 la decisión del Consejo de Calificación Cinematográfica es un órgano jurisdiccional que ejerce jurisdicción $\mathrm{y}$, por ende, sus fallos producen cosa juzgada, es decir, tornan al acto administrativo en firme y definitivo, inamovible y jurídicamente intangible.

En mi modesto parecer, esta postura es incorrecta por lo siguiente:

1) Si bien el marco regulatorio del Consejo de Calificación Cinematográfica establece una instancia de apelación frente al rechazo de un filme, éste no es un tribunal que ejerza jurisdicción, ya que no resuelve conflictos intersubjetivos entre partes. En efecto, el artículo 11 del Decreto Ley del año 1974 que creó el Consejo de Calificación Cinematográfica señala, en lo pertinente:

"Sólo se podrá apelar de la calificación "rechazada". El interesado podrá hacerlo dentro del plazo de cinco días, contados desde la notificación del fallo del Consejo, a un Tribunal de Apelación formado por el Ministro de Educación Pública, el Presidente de la Corte Suprema, el Presidente del Colegio de Abogados y el Jefe del Estado Mayor de la Defensa Nacional. El Tribunal de Apelación sesionará con tres de sus miembros, a lo menos, y fallará sin ulterior recurso. En caso de empate en la votación decidirá el Presidente del Tribunal".

En consecuencia, estamos en presencia de un típico caso de recurso jerárquico, que en ningún caso genera cosa juzgada. De no ser así, se produciría el absurdo que sería mejor no ejercer los derechos que te franquea la ley, esto es, apelar, que ejercerlos. En efecto, si se postula que las resoluciones emanadas del Tribunal de Apelación son inmodificables, convendría no apelar de los rechazos del Consejo de Calificación Cinematográfica, ya que al no ejercerse ese derecho dicho órgano podría perfectamente proceder a recalificar a posteriori; mientras que si se apela y el tribunal de apelación confirma el rechazo, el Consejo de Calificación Cinematográfica quedaría desprovisto de su facultad de calificarlo nuevamente.

2) Si bien existen órganos del Estado diferentes al judicial que también ejercen jurisdicción, tales como el Senado en el denominado juicio político, sus facultades jurisdiccionales son de carácter excepcional. Lo anterior se desprende de concebir la jurisdicción, de la cual

46 Sayagués Laso, Enrique. "Derecho Administrativo”, Tomo I, Montevidẻo, 1953, p. 487, citado por Pereira Anabalón, Hugo. Op. cit., p. 6. 
emana la cosa juzgada, como el poder deber del Estado para resolver conflictos intersubjetivos de relevancia jurídica, concepción que no puede ser aplicada al órgano de apelación del Consejo de Calificación Cinematográfica, el cual en ningún caso puede catalogarse como tribunal de carácter jurisdiccional. Ello porque de ser así existirían controles jerárquicos de los Tribunales Superiores de justicia, los cuales en el caso en comento no existen.

3) Quien ha tratado con detención el tema de la cosa juzgada administrativa es la ex Ministra de Justicia del Gobierno Militar, doña Mónica Madariaga Gutiérrez, quien señala:

"La cosa juzgada está referida a la inmutabilidad de los actos administrativos. La posibilidad de que un acto dictado por el administrador pueda ser revocado a su arbitrio, implica un estado de absoluta inseguridad. Es por ello que, aún cuando la doctrina en general no acepta la teoría de la cosa juzgada en el campo de los actos administrativos, hemos estimado de interés analizarla desde el punto de vista de la seguridad jurídica. Su órbita de acción, a diferencia de la prescripción, está ubicada sobre la facultad ejercida, y consiste en dar a ésta una inmutabilidad o permanencia necesaria para la certidumbre en cuanto a la estabilidad de su contenido normativo" 47 .

Luego la autora añade:

"La cosa juzgada, al igual que la prescripción, provee a la seguridad jurídica mediante el establecimiento de límites normativos a la modificación y revocación de los actos administrativos. Específicamente, elimina la eventual derogación de los preceptos administrativos por causas no previstas en el sistema positivo" 48 .

\section{En seguida, manifiesta:}

"Nacida la noción de cosa juzgada en el ámbito del derecho procesal, se ha dicho que ella es consecuencia propia y exclusiva de las sentencias jurisdiccionales, las que, con fuerza de verdad jurídica, declaran la existencia de un derecho o de una situación preexistente. Por este motivo, su concepto no podría ser transplantado al campo de la administración, desde el momento que a éste no le incumbe, como a la justicia, la declaración del derecho, el establecimiento de una verdad jurídica inamovible o, por lo menos, una pretensión de verdad, sino tan sólo la satisfacción inmediata y directa del interés público. Sin embargo, no han sido pocos los autores que han aceptado usar el término cosa juzgada para explicar el fenómeno de la inmutabilidad de los actos administrativos" 49 .

\section{Posteriormente, estima:}

"Examinando el problema desde el ángulo de la seguridad jurídica, desaparece la importancia práctica de la distinción entre cosa juzgada e inmutabilidad o intangibilidad y el origen histórico de cada uno de estos términos, adquiriendo relevancia sólo el análisis de los efectos temporales de las manifestaciones jurídicas" ${ }^{50}$.

\footnotetext{
47 Madariaga Gutiérrez, Mónica. Op. cit., p. 199.

48 Ibid.,pp. 199 y 200.

49 Ibid., p. 200.

50 Ibid., p. 201.
} 
Finalmente, la autora estima:

"Se ha estimado preferible, a pesar de las críticas doctrinarias al concepto, emplear la expresión cosa juzgada para referirse a los límites del ejercicio de la potestad revocatoria, porque en este concepto más amplio pueden quedar comprendidos todos los fundamentos de la irrevocabilidad de los actos administrativos basados en la inmutabilidad de una norma frente a otra posterior" ${ }^{\text {51. }}$.

En consecuencia, para la autora interesa darle a los administrados un grado de seguridad y certeza, en el sentido que los actos administrativos que les otorguen derechos adquiridos no puedan ser alterados por la administración, generando una inmutabilidad o intangibilidad de ellos.

4) Plantear que en la administración hay cosa juzgada implicaría señalar que el administrador no podría invalidar sus actos contrarios a derecho, lo cual vulnera abiertamente el artículo 6 de la Constitución. Lo que ocurre es que la administración no puede desconocer los derechos válidamente adquiridos por los administrados, eso es obvio. Pero ello no impide que dicho órgano pueda dejar sin efecto los actos contrarios a derecho, que, además, no han generado derechos adquiridos para nadie, ya que ninguna persona podría considerarse poseedora del derecho a no poder ver una película.

En consecuencia, no estamos en presencia de un tribunal que ejerce jurisdicción, sino de una simple autoridad jerárquica que ejerce potestad administrativa, para lo cual debe ceñirse a la legalidad vigente, por lo que su decisión en ningún caso genera la autoridad de cosa juzgada.

De este modo, aunque el Decreto Ley que establece y regula las funciones del Consejo de Calificación Cinematográfica no le otorgue a este ente la potestad expresa de revocar sus actos por motivo de mérito, sí los puede revisar por motivos de ilegalidad, sea esta coetánea a su nacimiento, o bien sobreviniente; es decir, sus decisiones no son, en ningún caso, inamovibles ni jurídicamente intangibles.

Con respecto al problema planteado por la ausencia de una norma expresa que autorice al Consejo de Calificación Cinematográfica a revisar sus decisiones prohibitivas, concordamos con Rodrigo Castillo y Andrés Mena, quienes abordaron este tema con extrema claridad ${ }^{52}$. Ellos señalaron:

"Consideramos que este es el mejor argumento para sustentar las sentencias (que fallaron el recurso de protección en el caso "La Última Tentación de Cristo"), pues se basa en el principio de que en Derecho Público no puede hacerse sino aquello que está expresamente permitido”. Luego continúan:" "...hemos explicado que de acuerdo al precepto legal referido (D.L. N ${ }^{\circ} 679$ de 1974), el Consejo tiene facultades para revisar, a solicitud del Ministro de Educación, los acuerdos que hayan autorizado la exhibición de películas en el período anterior al 30 de septiembre de 1973, y no para revisar acuerdos denegatorios, cual sea su fecha. Por último, la ley y su reglamento señalan que el pronunciamiento denegatorio es definitivo.

51 Ibid., p. 202.

52 Castillo M., Rodrigo y Mena O., Andrés. "Análisis Crítico del Fallo Recaido en la prohibición del Filme La Última Tentación de Cristo", memoria para optar al grado de Licenciado en Ciencias Jurídicas y Sociales, Universidad de Chile, 1998. 
La interpretación referida tiene un sostén dogmático-jurídico razonable, utiliza racionalmente la técnica de interpretación a contrariu sensu, y analiza sistemáticamente el cuerpo legal pertinente. No obstante, consideramos que ello no basta para impedir una recalificación de una película prohibida. En perfecta concordancia con la interpretación garantista y finalista de normas con efecto en los derechos constitucionales, debe entenderse que toda interpretación de restricciones sobre tales derechos (libertad de expresión e información) debe ser muy estricta. Particularmente deberá serlo en el caso que el derecho de que se trate traiga aparejadas consecuencias políticas y jurídicas de tal importancia como las que se refieran a la libertad de expresión, bien tan caro para los sistemas democráticos. No es por lo tanto aventurado sostener que toda autoridad, que tiene facultad para restringir un derecho, tiene implícita la de dejar sin efecto la restricción. En este sentido hacemos notar, por ejemplo, que si bien la Constitución deja claramente establecida la forma y competencia para que la República entre en estado de guerra (Art. $32 \mathrm{~N}^{\circ} 21$ y $60 \mathrm{~N}^{\circ} 15$ de la Constitución), nada señala respecto a quién y cómo puede cesar este estado" 53 .

\section{Luego continúan los autores:}

"¿Significa eso que el Estado de Chile carece de facultades legales para hacer cesar un estado de guerra, al no haber norma expresa que resuelva el problema? En este sentido recalquemos que la ley no prohíbe expresamente la recalificación. Si bien podrá sostenerse que no la consagró expresamente, el que no la haya prohibido significa que el legislador no quiso llegar tan lejos como vetar para siempre una manifestación cultural" 54 .

\section{b. La revocación de los actos administrativos:}

Tal como se señaló, los fallos del recurso de protección sólo se refirieron a la forma de extinción del acto administrativo denominada revocación, esto es, aquella que tiene como origen el mérito, oportunidad o conveniencia, vale decir, cuando la ponderación del bien común así lo hace aconsejable, pero nada dijeron del decaimiento ni menos de la invalidación. Y no podía ser de otra forma, ya que en el expediente ninguna de las partes planteó la posibilidad de la extinción del acto administrativo del año 89 por ilegalidad sobreviniente.

De este modo, creo que perfectamente podía haberse planteado que el acto administrativo de 1989 había decaído por ilegalidad sobreviniente, por lo que el acto del '96 sólo había constatado esta situación provocada por la incorporación a nuestro ordenamiento jurídico, el año 1991, de la Convención Interamericana de Derechos Humanos.

Mucho se ha discutido en doctrina acerca de la real existencia del decaimiento del acto administrativo. En efecto, algunos autores como don Enrique Silva Cimma estiman que dicha causal de extinción de los actos administrativos:

“...no es otra cosa que un espejismo sin mayor asidero; no es más que una falacia jurídica. ¿Por qué? Porque dentro de nuestra concepción no se puede concebir que esto sea una modalidad especial de extinción del acto administrativo" 55 . 
De este modo, para cierta parte de la doctrina el decaimiento no configuraría una causal de extinción de los actos administrativos diferente a la invalidación, revocación o nulidad. Siguiendo esta doctrina, surge la interrogante, ¿¿dentro de cuál clasificación caería una ilegalidad sobreviniente de un acto administrativo?

En mi modesto parecer, y no obstante estimar que conviene hablar de decaimiento del acto administrativo para precisar correctamente el ámbito de acción de las diversas causales de extinción de dichos actos, estimo que caería dentro del concepto de invalidación. En efecto, se ha definido la invalidación como aquella causal de extinción del acto administrativo realizada por la administración activa mediante la cual ésta deja sin efecto un acto administrativo por causa de ilegalidad ${ }^{56}$. De este modo, y en virtud del principio de juridicidad consagrado por los artículos 6 y 7 de la Constitución, pesa sobre la administración:

“...la obligación de ajustar sus decisiones a las normas que regulan las materias que en ellas recaen, correspondiéndole a la misma administración dejar sin efecto sus medidas ilegales o basadas en presupuestos anómalos o en que se haya incurrido en errores de hecho que afecten sus presupuestos jurídicos, aun cuando ellas hayan sido cursadas sin objeción por la Contraloría, para así reestablecer el orden jurídico quebrantado por esas determinaciones." ${ }^{57}$

En consecuencia, los órganos de la administración que han dictado actos administrativos en contravención a la Constitución y a las leyes y que, en consecuencia, son nulos, deben retirar del ordenamiento esos actos contrarios a derecho, dictando al efecto otro acto que los derogue o deje sin efecto, invalidándolos, reestableciendo así dicho ordenamiento quebrantado. Sin embargo, continúa el profesor Soto Kloss, es jurídicamente improcedente el ejercicio de tal potestad invalidatoria por parte de la Administración si el acto administrativo ilegal ha producido efectos y ellos han ingresado al patrimonio de terceros de buena fe, ya que los errores de la Administración deben ser soportados por ella misma y jamás ser cargados a terceros enteramente ajenos a su torpeza. Además, habiéndose producido los efectos jurídicos del acto administrativo defectuoso, dichos efectos devienen adquiridos y, por lo tanto, protegidos y asegurados por la propia constitución (Art. $19 \mathrm{~N}^{\circ} 24$ y Art. 20 inc. $1^{\circ}$ ), pues para sus beneficiarios constituye un derecho de propiedad." 58

Si bien el profesor Soto Kloss considera al decaimiento como una causal de extinción de los actos administrativos, concretamente de sus efectos ${ }^{59}$, he citado sus artículos con el fin de analizar la posible vinculación entre dicha causal y la invalidación.

Siguiendo dicha tesis, si la administración se encuentra obligada a dejar sin efecto los actos administrativos contrarios a la constitución y a la ley, deberá invalidar dicho acto mediante la dictación de otro acto que restablezca dicho ordenamiento, independiente si dicha contravención es coetánea al nacimiento del acto o es posterior. En consecuencia, la invalidación puede ocasionarse por una ilegalidad ab initio, es decir, al momento de dictación del acto administrativo, o sobreviniente, a posteriori de su entrada en vigencia.

\footnotetext{
Ibid., p. 158.

Soto Kloss, Eduardo. "La Invalidación de los Actos Administrativos en el Derecho Chileno", Rev. Derecho y Jurisprudencia, T. LXXXV, N³, 1988, Primera Parte, p. 162.

Ibid.

Soto Kloss, Eduardo. Curso de Derecho Administrativo, Santiago, Escuela de Derecho, Universidad de Chile, 1997.
} 
Pero esta potestad invalidatoria, a juicio del profesor Soto Kloss, tiene límites. En efecto, a su juicio al administrador le está vedado invalidar un acto administrativo ilegal si éste ha producido efectos y ellos hàn ingresado al patrimonio de terceros de buena fe. Estima que en tal caso la autoridad administrativa carece del poder jurídico de invalidar (potestad de autotutela declarativa), por lo cual si estima que ha incurrido en un error al dictar el acto administrativo que ella pretende es ilegal o más bien antijurídico, debe recurrir al juez para que éste declare en el correspondiente debido proceso lo que sea de Derecho, vale decir, si es o no ajustado a derecho dicho acto administrativo cuya juridicidad se controvierte" 60 .

Esta última postura del profesor Soto Kloss, es decir, si la administración posee o no la potestad de invalidar los actos administrativos ilegales que han producido efectos que, a su vez, se han incorporado al patrimonio de terceros de buena fe, ha sido cuestionado por algunos autores. En efecto, y tal como lo veremos más adelante, los profesores de Derecho Administrativo Pedro Pierry Arrau y Jorge Reyes Riveros tienen una posición del todo diversa.

No obstante lo interesante de esta discusión doctrinaria, y asumiendo por un instante que el decaimiento no es más que una forma de invalidación por ilegalidad sobreviniente, surge la siguiente interrogante: ¿Podría invalidarse el acto administrativo de 1989 mediante la dictación de un nuevo acto dictado por el Consejo de Calificación Cinematográfica?

Ello es del todo posible, atendido los siguientes argumentos:

1) Desde la dictación del acto administrativo del año 1989 a la fecha se han producido una serie de alteraciones en nuestro ordenamiento jurídico. En efecto, el año 1990 Chile ratificó el Pacto de San José de Costa Rica, el cual pasó a formar parte integrante de la normativa nacional, cualquiera sea el rango o jerarquía que se le otorgue. Además, y atendido que la Corte Interamericana condenó a Chile en el caso que nos ocupa, tenemos un fallo de dicho Tribunal que declaró responsable a nuestro país y lo obliga a cumplir ciertas prestaciones.

2) El acto administrativo de 1989 que censuró el filme es un acto de carácter restrictivo, ya que impide la exhibición pública de la película y, por ende, restringe los derechos de muchas personas con criterio a formarse su propia opinión sobre el tema controvertido. $\mathrm{Al}$ ser un acto administrativo de carácter restrictivo, puede ser dejado sin efecto.

3) La invalidación es aquella causal de extinción del acto administrativo realizada por la administración activa mediante la cual ésta deja sin efecto un acto administrativo por causa de ilegalidad que, interpretando, concluimos que puede ser coetánea al nacimiento del acto o sobreviniente.

4) Con respecto a la facultad de la administración para invalidar sus actos hay diversas posturas. En efecto, el profesor Soto Kloss, en términos muy generales, plantea lo siguiente:

a) Por el principio de juridicidad, los órganos de la Administración, que han dictado actos administrativos en contravención a la Constitución y a las leyes, deben retirar del ordenamiento jurídico dichos actos contrarios a Derecho, dictando al efecto otro acto que los derogue o deje sin efecto, invalidándolos, restableciendo así dicho ordenamiento quebrantado;

b) Pero esta potestad invalidatoria no es absoluta, ya que le está vedado a la Administración el ejercicio de tal potestad si el acto administrativo ilegal ha producido 
efectos y ellos han ingresado al patrimonio de terceros de buena fe mediante derechos que devienen adquiridos y, por ende, protegidos por el Art. $19 \mathrm{~N}^{\circ} 24$ y Art. 20 de la Constitución, ya que para sus beneficiarios constituye un derecho de propiedad; y c) En estos casos, la autoridad administrativa carece del poder jurídico para invalidar, por lo que si estima que el acto administrativo es ilegal y antijurídico, debe recurrir al juez para que declare lo que corresponda ${ }^{61}$.

Por el contrario, los profesores Reyes Rivera y Pierry $\mathrm{Arrau}^{62}$, en términos generales, estiman:

a) En virtud del Art. $6^{\circ}$, inciso $1^{\circ}$ de la Constitución, la administración, si advierte que se ha quebrantado el principio de juridicidad, se halla obligada a reestablecer el orden jurídico quebrantado, dando cumplimiento al deber que dicha norma le impone; es decir, puede y debe invalidar sus actos contrarios a Derecho;

b) Esta facultad invalidatoria de la administración está consagrada, entre otras, por las siguientes normas: Art. $6^{\circ}$ y $32 \mathrm{~N}^{\circ} 8$ de la Constitución; Art. $2^{\circ}, 3^{\circ}, 8^{\circ}, 9^{\circ}$ y $10^{\circ}$ de la Ley Orgánica Constitucional de Bases Generales de la Administración del Estado; Art. 154 y 156 de los Estatutos Administrativos Generales y Municipal; y otros, como los artículos 136 de la Ley $N^{\circ} 18.695$ y 102 de la Ley 19.175; y

c) Con respecto a la pregunta si tendría la calificación de acto expropiatorio aquel que invalida un acto que concede un determinado beneficio, señalan que el acto invalidatorio de la administración es de carácter declarativo, ya que él sólo ha de declarar la existencia de la infracción al principio de juridicidad y, como consecuencia, anulará el acto administrativo viciado, pero no va a privar ni atribuir dominio a nadie.

De este modo, y siguiendo la tesis de la invalidación sustentada por los profesores Reyes y Pierry, debemos concluir que la administración está facultada para invalidar sus actos cuando éstos tengan un vicio de legalidad. Si bien estos profesores sólo se refieren a la ilegalidad coetánea al nacimiento del acto, creo que esta misma postura es extrapolable para el evento que dicha ilegalidad sea sobreviniente. Es decir, pensamos que un acto que nació sin vicios puede tornarse ilegítimo o antijurídico por el cambio de las circunstancias jurídicas existentes al tiempo de su dictación. En consecuencia, en virtud de esta posición doctrinaria, la administración se encuentra facultada para invalidar los actos que, naciendo sanos, se transforman en ilegales por una causa legal sobreviniente; es decir, puede y debe invalidar sus actos contrarios a derecho. ${ }^{63}$.

Algunos fallos recientes han avalado esta última postura, reconociendo la facultad de la administración de invalidar los actos administrativos contrarios a derecho. En efecto, la

6) Esta imposibilidad de invalidar los actos administrativos que han producido efectos que han ingresado al patrimonio de terceros de buena fe ha sido controvertido por algunos autores, tales como los profesores Pedro Pierry Arrau y Jorge Reyes Riveros, en "Nulidad en el Derecho Administrativo", Revista de Derecho de la Universidad Católica de Valparaíso, Tomo XV, 1993-1994,pp. 84 y 85; “ "La Nulidad de Derecho Público”, Edit. Jurídica Conosur, Santiago de Chile, 1998, respectivamente,

61 Soto Kloss, Eduardo, extractado de apuntes de clase, curso Derecho Administrativo, Facultad de Derecho Universidad de Chile, 1996; “ “La Invalidación de los Actos Administrativos en el Derecho Chileno", R.D.J. Tomo LXXXV-N³-1988.

62 Reyes Riveros, Jorge. Op. cit., pp. 43 y ss.; Pierry Arrau, Pedro. Op. cit., pp. 84 y 84.

63 Reyes Riveros, Jorge. Op. cit., p. 53. 
Excma. Corte Suprema, conociendo en segunda instancia de un recurso de protección interpuesto en contra del Director de Obras de la Municipalidad deViña del Mar, estableció la siguiente doctrina:

"Si el acto que dicta una autoridad administrativa carece de fundamento normativo por cuanto su actor está desprovisto del ejercicio de determinadas atribuciones en razón de haberse dispuesto el congelamiento urbanístico sobre un sector del territorio comunal, resulta procedente su invalidación dada la gravedad del vicio de que adolecía." ${ }^{4}$

De los diversos considerandos de la mencionada sentencia se desprende una serie de principios:

i) Que la acción ejecutada por el Director de Obras de la Municipalidad de Viña del Mar, al dejar sin efecto un permiso de obra nueva, corresponde al ejercicio de la atribución de la autoridad administrativa de retirar sus actos si verifica posteriormente que su legitimidad adolece de vicios. (Considerando $1^{\circ}$.)

ii) El fundamento de esa atribución reside en la misma potestad de que está investida dicha autoridad para dictar actos administrativos, la que también encierra la de invalidar aquellos que son contrarios al ordenamiento jurídico. (Considerando 2.)

iii) La invalidación de un acto viciado de ilegalidad responde a la plena observancia del principio de legalidad que enmarca el accionar de la administración y de todos los órganos del Estado, que, entre otras normas, recogen los artículo 6 y 7 de la Constitución y 2 de la Ley $N^{\circ} 18.575$. (Considerando $3^{\circ}$.)

iv) La facultad de la administración de retirar sus actos contrarios a derecho, invalidándolos para restablecer el orden jurídico perturbado, mediante un nuevo acto de contrario imperio, pertenece, por su naturaleza, al ámbito de la función administrativa. (Considerando $9^{\circ}$.)

v) Siendo la potestad de invalidación un asunto comprendido en la actividad administrativa del Estado, su ejercicio no significa invadir el ámbito de la función jurisdiccional que compete privativamente a los tribunales establecido por ley. (Considerando $11^{\circ}$.)

vi) La potestad de la autoridad administrativa de retirar sus actuaciones resueltas en contravención al ordenamiento jurídico, a través de un nuevo acto administrativo invalidatorio, no coloca a los afectados en indefensión porque la nueva decisión administrativa puede ser impugnada mediante los recursos administrativos o jurisdiccionales que consulta al efecto la normativa vigente, v.gr. Art. 9 de Ley $\mathrm{N}^{\circ} 18.575$ y Art. 20 de la Constitución Política de la República, respectivamente. (Considerando $16^{\circ}$.)

vii) No debe incurrirse en la confusión de asimilar la situación de los beneficiarios directos de una actuación irregular de la administración de los terceros de buena fe, a quienes la invalidación o anulación del acto administrativo no puede afectar en los mismos términos, por cuanto los destinatarios inmediatos de una actuación adminis-

64 Excma. Corte Suprema, 20 de octubre de 1999, recurso de protección, R.D.J., tomo XCVI, segunda parte, sección quinta, 1999,pp. 175 a 183. 
trativa unilateral no son terceros en esa relación, especialmente si han solicitado voluntariamente la dictación del acto irregular invalidado. (Considerando $22^{\circ}$.)

5) No obstante lo anterior, e incluso siguiendo la tesis del profesor Soto Kloss, se obtiene igual conclusión. En efecto, el profesor Soto Kloss no excluye totalmente que la administración pueda invalidar sus actos, sino sólo limita o restringe considerablemente dicha facultad. Tal como lo enunciamos precedentemente, el académico plantea que la administración está desprovista de la facultad de invalidar los actos administrativos cuando éstos han producido efectos y se han incorporado al patrimonio de terceros de buena fe. En el caso del acto administrativo dictado el año 1989, que censuró el filme, no hay derechos adquiridos, ya que nadie podría en forma seria pretender que la imposibilidad o prohibición de ver el filme forma parte de su patrimonio, ya que no existe un derecho real o personal que pueda verse vulnerado.

\section{Consideraciones finales}

Luego de todo lo analizado precedentemente, podemos señalar, en forma categórica, que la hipótesis de cumplimiento del fallo denominada "Extinción del acto administrativo" es plenamente aplicable a la sentencia condenatoria dictada por la Corte Interamericana de Derechos Humanos el 05 de febrero de 2001. En efecto, y tal como lo analizamos precedentemente, el acto administrativo dictado por el Consejo de Calificación Cinematográfica el 29 de noviembre de 1988, confirmado por el tribunal de apelación el 14 de marzo de 1989, forma parte integrante del ordenamiento jurídico chileno, producto de lo cual puede decaer o ser invalidado por la propia administración por ilegalidad sobreviniente. Así las cosas, una vez extinguido el acto administrativo por el Consejo de Calificación Cinematográfica, éste deberá dictar un nuevo acto que califique la película en alguna de las categorías establecidas en la ley, alterándose el ordenamiento jurídico vigente hasta hoy.

Entonces, aplicando la tesis de la extinción del acto administrativo, se cumple a plenitud con el fallo dictado por la Corte Interamericana de Derechos Humanos, ya que se modifica el ordenamiento jurídico nacional y se permite la exhibición del filme "La Última Tentación de Cristo".

Lo anterior guarda perfecta armonía con los principios generales de derecho, ya que la sentencia condenatoria emanada del tribunal internacional sólo produce efecto respecto de la causa en que se pronunció, sin que pueda hacerse extensiva a otros casos de censura previa, que no es más que la aplicación del principio consagrado en el inciso $2^{\circ}$ del artículo $3^{\circ}$ de nuestro Código Civil, el cual dispone:

"Las sentencias judiciales no tienen fuerza obligatoria sino respecto de las causas en que actualmente se pronunciaren."

En consecuencia, resultaría absurdo plantear que el único mecanismo de cumplimiento del fallo sería esperar que el Poder Legislativo modifique la legislación vigente, ya que ello implicaría señalar que sólo forman parte del ordenamiento jurídico chileno las normas ema- 
nadas del Congreso Nacional. Incluso más, pretender algo como lo enunciado precedentemente significaría violar abiertamente el artículo 27 de la Convención de Viena sobre Derecho de los Tratados, ya que se estaría condicionando el cumplimiento de una sentencia judicial, que obliga a Chile, a una modificación legal ${ }^{65}$.

Es por esto que el Consejo de Calificación Cinematográfica, como órgano de la administración del Estado, puede y debe cumplir de inmediato la condena impuesta al Estado de Chile por la Corte Interamericana de Derechos Humanos. Para ello debe modificar el ordenamiento jurídico mediante la extinción del acto administrativo dictado el 29 de noviembre de 1988 y confirmado por el tribunal de apelación el 14 de marzo de 1989, por ser contrario a derecho, procediendo luego, mediante un nuevo acto, a calificar el filme en alguna de las categorías establecidas en la ley para permitir definitivamente su pública exhibición.

\section{Conclusiones}

De los diversos acápites del presente trabajo se pueden extraer las siguientes conclusiones:

1. El fallo dictado por la Excma. Corte Suprema el 17 de junio de 1997 dejó sin efecto el acto administrativo dictado por el Consejo de Calificación Cinematográfica que el 11 de noviembre de 1996 autorizó la exhibición del filme "La Última Tentación de Cristo".

2. Al quedar sin efecto el acto administrativo dictado por el Consejo de Calificación Cinematográfica que autorizó la exhibición del filme, recuperó plenamente su vigencia el acto administrativo dictado por el mismo ente el 29 de noviembre de 1988 , confirmado el 14 de marzo de 1989, que prohibió la exhibición de "La Última Tentación de Cristo". En efecto, nuestro máximo tribunal confirmó el fallo de la Iltma. Corte de Apelaciones que, en la parte resolutiva pertinente, señala:

“....se acoge el recurso de protección deducido a lo principal de fojas 13 , y se declara que se deja sin efecto la resolución administrativa del Consejo de Calificación Cinematográfica adoptada en sesión $\mathrm{N}^{\circ} 244$, del 11 de noviembre de 1996, quedando, en consecuencia, firme aquella de 29 de noviembre de 1988 , confirmada mediante el fallo del tribunal de apelación cuya copia se lee a fojas 151, de fecha 14 de marzo de 1989".

3. La Convención Interamericana de Derechos Humanos o Pacto de San José de Costa Rica fue ratificada por Chile el año 1990, siendo publicada en el Diario Oficial el 5 de enero de 1991, incorporándose a nuestro ordenamiento jurídico y pasando a ser norma obligatoria para nuestro país, cualquiera sea la postura que se asuma respecto a la jerarquía de los tratados internacionales sobre Derechos Humanos ratificados por Chile y que se encuentren vigentes. Ello en atención a que el D.L. 679 que regula al Consejo de Califi-

65 El artículo 27 de la Convención deViena sobre Derecho de los Tratảdos señala: "Una parte no podrá invocar las disposiciones de su Derecho interno como justificación del incumplimiento de un tratado..." 
cación Cinematográfica, cuyo artículo 8 letra f) permite rechazar y por ende censurar filmes, es del año 1974, y el Pacto de San José de Costa Rica de 1991 (D.O. 5 de enero de 1991). Por ende, sea que consideremos al Pacto de San José de Costa Rica una norma de rango constitucional o simplemente legal, llegamos a la misma conclusión, cual es que el acto administrativo del año 1989, dictado conforme al D.L. 679 de 1974, se tornó ilegal por causa sobreviniente a la entrada en vigencia del referido tratado internacional.

4. El acto administrativo del año 1989, que prohibió exhibir el filme, fue válidamente dictado por el Consejo de Calificación Cinematográfica, ya que se adecuó a toda la normativa vigente a esa época. Pero una vez incorporado a nuestro ordenamiento jurídico la Convención Americana de Derechos Humanos, los efectos de dicho acto decayeron -tornándose ilegales- en virtud del artículo 13 de dicho Pacto que prohibió la censura previa.

5. Con posterioridad a la dictación del acto administrativo del año 1989 varió la legislación chilena sobre la materia, pasando a transformarse un acto enteramente lícito en ilícito por una situación sobreviniente, como lo fue la ratificación del Pacto de San José de Costa Rica el año 1991. De este modo, estamos en presencia de una causal de invalidación por causa sobreviniente, la que los autores denominan decaimiento o invalidación por causa sobreviniente, ya que el acto del año 1989 no adolece de vicios coetáneos a su nacimiento, sino que se tornó ilegal por un cambio de la legislación, que mutó de aquella que permitía la censura previa a una que la prohíbe expresamente.

6. Producto de lo anterior, el fallo condenatorio que dictó la Corte Interamericana de Derechos Humanos en contra del Estado de Chile no sólo obliga a este último a cumplirlo, sino que demuestra que en nuestro país rige desde el año 1991 el Pacto de San José de Costa Rica, el cual debe ser acatado.

7. Considerando tanto el fallo condenatorio como la incorporación indiscutida a nuestro ordenamiento jurídico del Pacto de San José de Costa Rica, queda de manifiesto que en Chile variaron las circunstancias jurídicas que existían el año 1989, época de dictación del acto administrativo que aún mantiene su vigencia. Es por esto que la ilegitimidad sobreviniente, que vicia dicho acto administrativo que nació sano, debe ser remediada por la administración, por intermedio del Consejo de Calificación Cinematográfica.

8. Bien sabemos que sobre la administración del Estado pesa la obligación de adecuar sus actos a la Constitución y a las normas dictadas de conformidad a ella, lo cual le impide tolerar la existencia de actos administrativos fundados en preceptos contrarios a la normativa vigente.

9. Entonces, el Consejo de Calificación Cinematográfica debe adecuar sus actos devenidos contrarios a derecho, dejando sin efecto el acto administrativo que censuró el filme en el año 1989 mediante el decaimiento o la invalidación sobreviniente, en atención a que la normativa hoy vigente, específicamente el artículo 13 del Pacto de San José de Costa 
Rica, prohíbe la censura previa, lo que se ve claramente confirmado por el fallo que condenó al Estado de Chile por haber violado dicha convención, sentencia que acredita sobradamente el cambio sobreviniente de las circunstancias jurídicas.

10. La extinción del acto administrativo por medio de la invalidación sobreviniente o el decaimiento es del todo aplicable a este caso, ya que el acto dictado por el Consejo de Calificación Cinematográfico en 1989 no sólo se transformó de legal a ilegal, sino que jamás generó derechos adquiridos para terceros, pues nadie puede pretender, en forma seria, ser titular del derecho a no poder ver el filme.

11. Esta hipótesis de cumplimiento del fallo dictado por la Corte Interamericana de Derechos Humanos en el caso "La Última Tentación de Cristo" se confirma al analizar la parte resolutiva de dicha sentencia. En efecto, dicho fallo condena al Estado de Chile a modificar su ordenamiento jurídico interno, en un plazo razonable, con el fin de suprimir la censura previa para permitir la exhibición de la película "La Última Tentación de Cristo".

12. En consecuencia y atendido que los actos administrativos forman parte integrante del ordenamiento jurídico, el Consejo de Calificación Cinematográfico puede y debe dejar sin efecto el acto dictado en 1989 que censuró el filme producto de su ilegalidad sobreviniente, para luego, mediante un acto de contrario imperio, dictar el nuevo acto administrativo que califique la película en alguna de las categorías establecidas en la ley, para así permitir su pública exhibición.

13. Si el Consejo de Calificación Cinematográfica actúa de dicha manera, el Estado de Chile cumpliría íntegramente con el fallo dictado por la Corte Interamericana de Derechos Humanos, ya que se estaría modificando el ordenamiento jurídico y permitiendo la pública exhibición de la película, sin necesidad de esperar una modificación legislativa sobre el particular. Así, nuestro país el día 5 de agosto del presente año-fecha en que se cumplen los seis meses establecidos en el fallo para que el Estado de Chile informe a la Corte Interamericana de Derechos Humanos sobre las medidas tomadas- podría dar cuenta a dicho tribunal que se ha modificado el ordenamiento jurídico interno, permitiendo la exhibición del filme, y las reformas constitucionales y legales están en un avanzado trámite para su aprobación, con lo cual quedaría de manifiesto que Chile, a través de sus diversos órganos, se encuentra comprometido con la comunidad internacional. 